

\section{Shirkah}

Journal of Economics and Business

Vol. 2, No. 1, January-April 2017

ISSN: 2503-4235 (p); 2503-4243 (e)

\section{Editor in Chief}

Sri Walyoto

\section{Editorial Boards}

Abu Umar Faruq Ahmad, UBD School of Business and Economics, Brunei Darussalam

Amelia Fauzia,

Asia Research Institute, National University of Singapore, Singapore

Cedomir Nestorovic,

ESSEC Business School Asia Pacific, Singapore

Dwi Condro Triono,

Faculty of Islamic Economics and Business, IAIN Surakarta, Indonesia

Fahmy Radhi,

Faculty of Economics and Business Universitas Gadjah Mada, Yogyakarta,

Indonesia

Hasan Basri,

Syiah Kuala University, Aceh, Indonesia

Johan Fischer,

Department of Social Sciences and Business Roskilde University, Denmark

Masudul Alam Choudhury,

Postgraduate Program in Islamic Economics and Finance, Trisakti University,

Jakarta, Indonesia and the College of Economics and Political Science (CEPS) in

Sultan Qaboos University (SQU), Oman

M. Falik Isbah,

School of Humanities and Social Science, University of New South Wales, Australia M. Ishaq Bhatti,

La Trobe Business School Department of Economics and Finance La Trobe

University, Australia

Najib Kailani,

Pascasarjana, Universitas Islam Negeri (UIN) Sunan Kalijaga, Yogyakarta, Indonesia 
Nunung Nurul Hidayah,

Aston Business School, Aston University, Birmingham, United Kingdom

Shaikh M Ghazanfar,

Departement of Economics, University of Idaho, Russian Federation

\section{Managing Editors}

Fitri Wulandari

Jasanta Perangin-angin

\section{Assistant to Editor}

M. Endy Saputro

M. Zainal Anwar

Supriyanto

Shirkah Journal of Economics and Business is a peer-reviewed journal published three times a year (January-April, May-August and September-December) by Faculty of Islamic Economics and Business, Institut Agama Islam Negeri (IAIN/ State Institute for Islamic Studies) Surakarta Central Java, Indonesia. The main objective of Shirkah is to offer an academic space of exchange ideas and initiate the increase number of qualified article produced by postgraduate students, practitioners and academicians.

\section{Editorial Office}

Ruang Jurnal Shirkah

Ground Floor, West Gate,

Faculty of Islamic Economics and Business

IAIN Surakarta

Jln. Pandawa No. 1, Kartasura, Sukoharjo, Jawa Tengah Kode Pos. 57168

Phone (+62271) 781516 Fax: (+62271)782336

E-mail: shirkahiainsurakarta@gmail.com

Website: http://shirkah.or.id/ 



\section{Shirkah}

Journal of Economics and Business

Vol. 2, No. 1, January-April 2017

ISSN: 2503-4235 (p); 2503-4243 (e)

\section{Table of Contents}

\section{Articles}

Ana Zahrotun Nihayah

Savings and Loans Program, The Revenue of Small Micro Entreprises and Poverty Reduction among Women Groups

Ana Fadhilah

Muslimah Entrepreneurship and Economic Empowerment in Pengajian

Umiyati

Local Economics Empowerment and Sharia Microfinance in Rural

Community Perception

Lathif Hanarif Rifqi

Community Empowerment through Islamic Microfinances Perceptions in Comparison

Ahmad Lukman Nugraha

Islamic Business Ethics and Islamic Microfinance in Pesantren Gontor

Nova Ch. Mamuaya

Service Quality and Non-Muslim Satisfaction Using Sharia Bank Products and Services 



\title{
Community Empowerment through Islamic Microfinances Perceptions in Comparison
}

\author{
Lathif Hanarif Rifqi \\ Faculty of Islamic Economics and Business \\ IAIN Surakarta \\ hanafirrifqi@gmail.com
}

\begin{abstract}
BMT (Islamic saving and loan cooperative) has continuosly been one of the Islamic microfinance institutions playing a significant role in empowering economic society. There has been a number of research discussing on the effort, however none of them discussed on the perception between the empowers and the empowered group. Comparing these perceptions is a salient effort to find similarities or differencess of perceptions. This research seeks to compare empowerment perception between two organizations. On one hand, the first party taking BMT BIF Ledok Timoho as the empowering organization and on the other hand focusing on a group of women's empowerment Ledok Timoho. Gathering data through doing observation and in-depth interview had been employed with selecting the purposive informants that contains a BMT BIF and four empowerment group representatives. To conclude, this research found that are similarities of perceptions on empowerment goals, process, outcomes and constraints.
\end{abstract}

Keywords : perception, empowerment, BMT (Islamic saving and loan cooperative)

\section{Introduction}

Implementation of empowerment must be supported by various parties. These parties may be individuals or institutions. In the context of the individual, Islam recommends to muzakki to be a driving force in empowerment. The movement of each individual muzakki can not be optimal without any systematically institutional coordination. Therefore, the existence of institutions to run the empowerment management is 
indispensable. One of the institutions that implement empowerment is BMT (Baitul Maal wa Tamwil).

BMT is one financial institution that has unique concept. The uniqueness is the ownership of the two functions, namely social and business (Ridwan, 2013: 24). Social functions run by division Baitul Maal, while Baitul Tamwil focuses in business affairs. Empowerment is a BMT social activities. Seem then that the implementation of empowerment more likely focused by Baitul Maal division (Wulandari, 2016). Much have been written on the empowerment of BMT. Muflihah (2011) examined the BMT contribution towards the economic empowerment of women in the region of South Tangerang. Muflihah's result showed a good contribution to the women as the empowered agents.

Muflihah findings take not much different from Rarasati's (2007) and Setyawati's (2002) ones. They carefully analyzes how the empowerment process carried out by BMT. The difference, although Rarasati also analyzes the impact of empowerment, take place while she added variables by analyzing the public response to empowerment BMT. In addition, Hardi (2013) academically investigates empowerment operated by BMT Beringharjo Yogyakarta. One purpose of the research was to analyze the effect of program, assistance quality, long working hours, and alms to revenue empowerment participants.

Some examples of those studies only focused on the measurement results of empowerment. This paper seeks to give different analysis on the perceptions of BMT empowerment. Perception takes an important role in the success of empowerment. The importance of perception in the empowerment are in the similarities or differences of perception among the involved parties. Comparison of perception has been analyzing from the higher degree, the easier and more frequent communication (Mulyana, 2003: 168). The existence of good communication encourage interaction 
raising cooperation to achieve successful empowerment program. The opposite condition where there is a difference of perception, then communication on the implementation of the empowerment would be determined.

BMT BIF empowerment on Ledok Timoho women's empowerment group is one form of empowerment that carried out by BMT. Based on the culprit, empowerment is done by the two parties. The first party is BMT $\mathrm{BIF}$ as the party that gives empowerment, while the second is a group of women's empowerment Ledok Timoho as the empowered party. This paper is an effort to analyze how perception comparison of the empowerment both of them happen. The empowerment perception comparison are objectives, process, results and constraints. The author argues that there is similarity of comparison among BMT BIF and Ledok Timoho women empowerment group referred to the four aspects, yet not of all aspects has difference.

Research locations took two places, namely: BMT BIF Jl. Rejowinangun Yogyakarta and Ledok Timoho Muja Muju Umbulharjo Yogyakarta. The data was gathered by observation and in-depth interview, through involving in conversation with such informants as Nur Ali, a representative of the BMT BIF, and the Ledok Timoho leaders such as Mrs. Haryani, Mrs. Syamsiyah, Mrs. Riyanti, and Mrs. Purwanti. Interactive model of data analysis, for which according Sugiyono (2008: 246-247), consists of three components: data reduction, data display, and conclusion / vertification. Data (perception) obtained from in-depth interviews, reduced to a certain amount of data (perception) required in studying variables. Perception is presented in the form of a sentence that is easy to understand. Perception presentation from BMT BIF and then followed by the perception of each group leader. The author further interprets the perception of BMT and each groups leader. 


\section{Perception and Empowerment}

Perception is the process that allows an organism to receive and analyze information (Rich, 1974: 17). Baron and Paul (1991: 34) said that perception is an internal process that allows one to choose, organize, and interpret stimuli from our environment, and the processes influences our behavior. Other opinion by Goodarce and Follers (1987: 30) that perception is a mental process used to identify the stimuli and DeVito (1997: 75) said, "Perception is the process that make us aware of the many stimuli affect our senses." These senses are the five senses of human beings. They are sense of touch, sense of sight, sense of smell, sense of taste, and sense of hear. On the other hand, perception is a means that allows someone to gain awareness of the surrounding environment (Sereno and Bodaken, 1975: 21). Based on the definitions, in this study perception defined as interpretation to object by their senses.

Perception consits of three things: sensation, attention and interpretation (Mulyana, 2003: 168). Sensation refers to a message sent to the brain through sight, hearing, smell, touch, and taste. Sensing devices will receive the stimulation after attention. Attention is the process of attention to an object. Attention inevitable because before responding or interpreting events or stimulation everything, must be first pay attention to the event or stimulus. This means that the perception requires the presence of an object to be perceived include others as well as myself.

The next stage is the interpretation. This stage is the most important stage in a perception. One can not interpret the meaning of an object directly, but to interpret the meaning of the trust representing the object. In other words, the knowledge gained from the perception is not the actual knowledge of the object, but the knowledge of how the object apparent. In fact, the perception of people with each other people can differ on the same object. This is because everyone has different abilities 
in sensing things. Perception differences also be caused by differences in experiencing and studying. Hardjana (2003: 40) argues that the perception is influenced by several things: experience, education, and culture. Fishers and Adams (1994: 57-62) also said that the social perception could be different because of the experience, selectivity, conjecture, evaluative, and contextual.

Mulyana (2003: 181) argues that there is a perception in the process of attention. Meanwhile, the attention is influenced by internal factors and social factors. Internal factors such as biological factors (hunger, thirst, etc.) and physiological (tall, short, fat, skinny, healthy, sick, tired, vision or hearing less than perfect, disability, etc.). Meanwhile, socio-cultural factors such as gender, religion, level of education, occupation, income, role, social status, past experiences, habits and psychological factors such as willingness, desire, motivation, hope, and so on.

There is no objective perception (Mulyana: 189). People do perceptions based on past experience and interests. Rodgers in Raymond (1983: 19) says that people do not react to the absolute reality but against perceived regarding the reality. Human life with perceptual maps that never was reality itself. In other words, the perception is very subjective nature according to his ability giving perception. Therefore, there arises the things that be a mistake or a failure of perception. The perception of failure is attribution error, hallo effect, stereotypes, prejudices, and culture shock.

Empowerment is a cooperation between the parties of empower and the empowered. Good cooperation requires good communication between the cooperating parties (Ngadiman, 2014). The result of communication is a perception. According to Mulyana (2003: 167) perception is the essence of communication, while interpretation is the essence of perception, which is identical to the encoding back (decoding) in the communication process. Therefore, the perception is depend on communication, on the other hand also depends on the perception of communication. 
The perception is influenced by several factors. The greater difference of aspects of these factors the greater difference in perception (Mulyana, 2003: 180). These difference of perception can interup communication because of the perception differences is one of the barriers of communication (Hardjana, 2003: 40). Bad communication will affect the cooperation agreement. However, differences of perception may also return likened to establish communication. As Cangara (2010: 165) said that all communication events that take place in a plan and goal, namely to influence the audience or recipient. The effect can occur in the form of changes in knowledge, attitudes, and behavior. At the level of knowledge of the effect may occur in the form of a change in perception or opinion. Basically, communication is a standard delivery, ideas, or ideas that clarify whether the executor has to know what will be done with clear, accurate, and consistent with the goals and objectives to be achieved (Wahyudi, 2014: 77).

Empowerment in bahasa comes from "daya", it means power or strength. Empowerment is an effort to build the community by encouraging, motivating, and raise awareness of the potentials and develop them (Mubyarto, 2000: 263). Another opinion defines empowerment is the process of directing the individuals of society to be able and willing to take part in decisions concerning their lives in the sphere of individual, community, and institutional (Mefalopulos, 2008: 232). Similar to, Safi'i (2010: 127) said that empowerment is to help clients gain the power to take decisions and do action related to them, including reducing the effects of personal and social barriers in action. While Pranarka in Sulistiyani (2004: 78) defines empowerment in two meanings. First, to give power or authority or provide power, transfer power or delegating authority to those who are less powerful. Second, to give ability to provide or enable or capability or empowerment as well as provide opportunities for others to 
do something. Based on the expert opinion of the above, in this study is defined empowerment as the stimulus given to individual or groups to be more empowered in some way in order to meet their needs.

The goal of empowerment is to realize the independence of the individuals or groups who are empowered. The independence includes independence of thought, action, and control of what is done. Thus to be self-sufficient human resource needs to support the ability of the intact form of cognitive abilities, conative, psychomotor, and affective, as well as other resources that are physical-material (Sulistiyani, 2004: 80). The independence is expected to individuals and groups empowered to meet their needs. Human needs according Widiastuti (2015: 40) is a basic requirement, psychological, social, and spiritual. Spesifically basic needs are clothing, food, shelter, health, and education. Psychological needs are mental functioning such as memory, learning, and intelligence, capacity adjustment, and personality. Social needs are the need for recognition of the existence of individuals in existence with others. Spiritual needs are the need for a philosophy of life, peace of life, the meaning of life, purpose in life, and the spirit of life. To get the goal, empowerment should through an empowerment process.

Empowerment process is a series of steps and actions taken to achieve the goal of empowerment. The process of empowerment regarding to efforts to improve the ability of individuals or groups by exploring all the potential possessed by an individual or group. The potential of the ability of expertise or knowledge. According Sulistiyani (2004: 83) empowerment is a process of learning which divided into several stages. They are awareness, transformation, and stages of capacity building. Awareness stage is the process directing the public to be aware of the potential of their resources. Thus, transformation of authority to manage their capabilities and skills. The last stage is 
increasing in intellectual abilities, skills, skills, in turn forming innovative initiative and ability to deliver on independence (Adnan, 2015).

\section{Picture 1}

\section{Empowerment Society Stage}
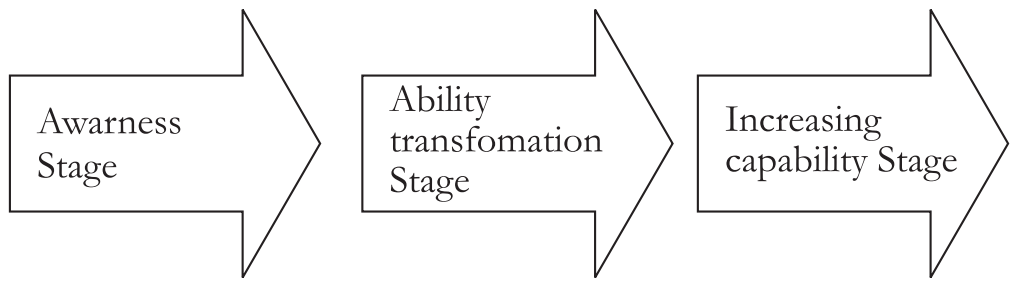

Source : Rahmawati (2015)

Another view of the empowerment stages said by Suhartini (2005: 135) that divides the empowerment process into six stages. First, the process of finding the problems that exist in the field. Secondly, an analysis of the problems in a participatory manner. Third, determine priorities which issues were resolved immediately. Fourth, look for alternative solutions. Fifth, carry out the execution to solve the problems faced. The final stage is an evaluation to examine the discrepancy between the expectations to what happened in the field. Results of empowerment can be measured by a variety of analysis tools. As research conducted by Nihayah (2014) that Simpan Pinjam Kelompok Perempuan (SPP) PNPM Mandiri Pedesaan give effect to changes in income micro small bussiness in Bangilan Tuban, East Java. In another study conducted by Hardi (2013) that the empowerment carried out by BMT Beringharjo Yogyakarta affect the income of the Muslim community empowered.

Using statistical measurement tools are needed to determine the extent of the success of development programs. The purpose of using statistical measuring instrument is to strengthen the perception expressed by the various parties involved in empowerment. However, statistical measuring tools have limitations on the number of respondents measured. 
Another result empowerment proposed by Setyowati (2014) that empowerment by PCM (Pimpinan Cabang Muhammaditah) Krembangan Surabaya to ex-prostitutes have been effective from three things: economic, social, and mental-religiosity. While Jati (2014) found that the PNPM program has no effect on poverty reduction in Mimika Papua 2009-2012.

In fact empowerment does not always work as planned. The failure is caused by a variety of obstacles. These constraints include the human resources (HR). Commonly, the human resource includes two parties are empower and empowered. The empower is the most empowering a role in empowerment (Wardiwiyono, 2012). They are usually referred to the powerful because duty to empower the weak or not powerless. The form of the activities is called mentoring and the excecutor called mentor team. The mentor team has a strategic role in supporting the implementation of the empowerment program. This is caused the quality of the mentor was instrumental approach the empowered community. Empowerment stage is ranging from awareness, transfer capabilities, and increased ability included assignment of mentor team. Therefore, mentor team quality has high value roles in the success of the three stages.

The mentor team should also be supported by the awareness of the community involved. This awareness and motivation in the form of serious intention to improve all the potential in order to achieve selfsufficiency. Society are required in all training and learning provided by the mentor team. Low awareness make the people to be passive into empowerment so that the implementation of the program constrained (Hadi, 2015). People awareness constrains were also found in the study expressed Diah (2013) on women's empowerment group in Tanjung Sea Tani Lestari Indah, South Bontang, Bontang. While Rahmawati (2015: 161-171) found obstacles in addition to the awareness that lack of insight into society, government regulation, and the interests of certain groups. 
Similar findings were obtained Wahyudi (2014: 76-87) which the research found obstacles empowerment in communication, human resources, natural resources, organizational form, character/ attitude of the empower, and attitudes.

\section{BMT (Baitul Maal wa Tamwil)}

Baitul Maal Wa Tamwil (BMT) is an independent business integrated consist of bayt al-mal wa tamwil that activities to develop productive ventures and investments in improving the quality of economic activities of small entrepreneurs by encouraging saving and supporting financing activities economy. In addition BMT can also accept deposit zakat, donation, and alms, as well as distribute it in accordance with the rules and mandate (Ridwan, 2013: 23). On the one hand, Arif (2012: 317) defined BMT as a microfinance institution that is operated by the principle of sharing to foster micro-enterprises in order to elevate the poor with regards based economic systems: safety (cored justice), peace, and prosperity. According to these two senses, conceptually BMT has two functions:

Bait at-tamwil (bait means house, at-tamwil means property development) activities developing productive ventures and investments in improving the economic quality of micro and small entrepreneurs, especially by encouraging the activities of saving and supporting the financing of economic activities.

Baital-Maal (bait means house, maal means treasure) receives deposits zakat, donation, and alms and optimize its distribution in accordance with the rules and trustment (Aziz, 2004:1).

BMT functions are divided into two ones, namely social focus (maal) and business (tamwil) is the uniqueness of BMT compared to other financial institutions. As an independent business BMT has the 
characteristics: first, the business-oriented, which aim to seek mutual profit and improve the utilization of all economic potential as much as possible for the members and the environment; second, is not a social institution, but can be used to manage the funds of social beings, like charity, donation, charity, grants and endowments; third, economic institutions beings are built from the ground independently involving the surrounding community participation; fourth, economic institutions owned jointly between the bottom and the small community and not owned by individuals or groups outside the community around the BMT (Ridwan, 2013: 24).

\section{Perception Comparison of Empowerment}

BMT BIF mentioned that the main goal of empowerment is improving economics. Other goals are religious and social. That perception is similar with each head of group empowerment. Mrs. Haryani and Mrs. Syamsiyah argued that the goals of empowerment consist of three things: economics, religious, and togetherness (social). Quite different opinion expressed by Mrs. Riyanti and Mrs. Purwanti that the goal of empowerment is only economics. Acoording that perception, empowerment goals asses by empowerment group are economics, religion, and social. With this perception, concluded that there are similarities in perception between BMT BIF with empowerment group Ledok Timoho. Their perception that empowerment has three goals. They are economic, religiousness, and social.

BMT BIF has perception that the concept of capital is a lend to each group according to the needs of the production of melin soap. BMT BIF use qard contract as a contract in lending capital. Qard contract with the borrower only refund the loan principal amount. In other words, no interest is required. In addition, BMT BIF also does not require collateral 
on the loan. However, in the contract, requirement include the BMT BIF infaq and savings in each installment. Mrs. Haryani does not have perception of the capital, because her group does not do the production of melin soap. Meanwhile, the Mrs. Syamsiyah, Mrs. Riyanti, and Mrs. Purwanti have similar perception of the capital. All three perceive that BMT BIF lend the amount of capital in accordance with the needs of each group in performing the production of melin soap. They also found capital loan interest and collateral is not required. However, they did not know the name of the qard contract. Mrs. Purwanti also added the information that the installments added infaq and savings. She assess that BMT gives leeway when there is delay in installments.

The perception between BMT BIF and empowerment group about capital has similarities. They have good perception on BMT BIF's capital. The concept of capital grant loans in accordance with the amount of capital required by each group were submitted. Regarding qard contract, the three groups that filed not know the definition of the contract. However, they understand the substance of the qard contract that do not require interest and collateral. In addition, the savings and loan installments with infaq. Soap making training in BMT BIF overall Aisyah and handed over to the participants empowerment. The training requires a proposal from the participants. Mrs. Syamsiyah has a relationship with Aisyah parties that can provide training. According that condition, BMT BIF has perception that the training has been going well.

Perception of the four informants was not much different about soap making training. They considered that the training went well as direct training with practice. In addition, the process of making soap that is not too complicated make the participants easy to understand. However, more critical comments by Mrs. Haryani. In her perspective, Aisyah does not give a description of the raw material of melin soap. 
According to Mrs. Haryani, raw material components of the melin soup should be conveyed to the participants empowerment. Assuming that perception, Mrs. Haryani suspect efficiency if the price of raw materials attached in the program. Mrs. Haryani also found in the training should be given guidance on marketing the goods. A similar opinion was also expressed by Mrs. Riyanti and Mrs. Purwanti that the training not given information about market access. Mrs. Purwanti also added, Aisyah also does not provide enough information about access to raw material. With this perception, concluded that there are differences in perception between BMT BIF with empowerment group on training. BMT BIF judge that soap making training has been going well, while the group's empowerment found the training does not run optimally. Not optimally points in training lies in information about raw materials and market access.

Mr. Ali as the representative of BMT BIF asses that religion program held once a month is effort to increase religious knowledge of participants. This program is also expected to increase solidarity between participants. Religion program is started by the speakers both BMT BIF or representative participants. However, it has always endeavored to invite a speaker from outside. Material lectures by Mr. Ali usually give a talk on live motivation. After it, BMT BIF evaluates the progress of empowerment. The last is gathering the custody of the participants.

Perceptions of religion program presented by Mr. Ali has similarities with empowerment group. Religion program conducted once a month is considered to be adequate. In addition, participants also suggested that the speaker's empowerment can be brought in from outside whom should be competent. This meant that the study did not show up the monotony of interest. Another suggest that was submitted by Mrs. Syamsiyah that should fill the talks were focused on the reward of a practice, not exposing the torture obtained by a deed. 
Perception of religion program submitted by BMT BIF and the head of each group empowerment mentioned above are similar to. In short, the perception of the parties concerning religion program is conducted routine once a month. In turn, it seek out the speakers of the event is competent to avoid monotony. In addition, the material contains a motivational talks addition, should emphasize to reward or advantage obtained from an act, not an emphasis on punishment. Evaluation of empowerment is rare, while the gathering is considered good enough.

Empowerment outcomes are three aspects. Those are economic aspect, religion aspect, and social one. Economic outcomes according BMT BIF perceptions is not good enough. This is caused by producing melin soap not optimal. BMT BIF also said that only three groups producing melin soap and only one that looks the most active group. Meanwhile, the BMT BIF assess all the participants have the skills to make soap. Similarity perception conveyed by the informant of empowerment group except Mrs. Haryani whose group not producing soap. Mrs. Syamsiyah, Mrs. Riyanti, and Mrs. Purwanti said that the production of melin soap can not give income enough. A few revenue got from producing melin soap. Inhibiting factor are raw material, marketing, and flurry participants.

To conclude that perception of empowerment outcomes in economic aspect is similar among BMT BIF with empowerment group. Their perception that empowerment does not give income enough yet. However, on the other hand empowerment participant has skills in making a soap. BMT BIF said that they can not accurately measure impact of religious program. However, by the simple observation, Mr. Ali said that religion program hasn't significant impact to them esspecially on religious increasing, moral improvement, and live motivation.

Similar perceptions expressed by Mrs. Haryani and Mrs. Syamsiyah, they said that many factors affect the increase in religious, 
moral improvement, and live motivation. In other words, they can not be only improved by religion program. Meanwhile, Mrs. Riyanti and Mrs. Purwanti also said that their worship is not so increased by religion program, but they have an increasing of motivation enough. According those perceptions, concluded that BMT BIF and empowerment group has similarities perception of empowerment outcomes in religion aspect. Their perceptions that empowerment has not been significat impact to worship, moral, and live motivation.

BMT BIF give an opinion that so far have been implemented empowerment can contribute to togetherness and intimacy of them. Furthermore, BMT added that with the meeting and the religion program can keep relationship between participants with BMT. Similar perceptions said by each group leader. In simple terms, they reveal that meetings/ religion program held by BMT impact togetherness and intimacy of them. According that perception, BMT BIF with empowerment group have the same perception of empowerment outcomes in social aspects. Empowerment outcomes of social aspect is the preservation of unity and increased familiarity among the participants.

There are similarities and differences of perception about empowerment constraints. BMT BIF and the empowerment group has similarities perception in marketing constraints, flurry of participants, and the awareness of the participants. Meanwhile, the different perceptions of contrains are limited access points raw materials and BMT staff. BMT BIF does not consider the difficulty of raw materials as an obstacle empowerment, but the difficulty of access to raw materials are perceived as obstacles by empowerment participants. Instead, limitation of BMT staff are perceived as an obstacle by BMT BIF, but from the perspective of the empowerment group that is not perceived as an obstacle. Comparison empowerment constraints presented as in the table below. 
Table 1

Perception Comparison about Empowerment Constrain

\begin{tabular}{|l|l|}
\hline \multicolumn{1}{|c|}{$\begin{array}{c}\text { Empowerment constrain } \\
\text { perception by BMT BIF }\end{array}$} & \multicolumn{1}{|c|}{$\begin{array}{c}\text { Empowerment constrain } \\
\text { perception by empowerment } \\
\text { group }\end{array}$} \\
\hline $\begin{array}{l}\text { 1. Difficulty of soap marketing } \\
\text { 2. Flurry of participants }\end{array}$ & $\begin{array}{l}\text { 1. Limited access to soap raw } \\
\text { materials }\end{array}$ \\
$\begin{array}{l}\text { 3. Low awarness of participants } \\
\text { 4. Limited of BMT staff }\end{array}$ & $\begin{array}{l}\text { 2. Difficulty of soap marketing } \\
\text { 3. Flurry of participants }\end{array}$ \\
& 4. Low awarness of participants \\
\hline
\end{tabular}

\section{Conclusion}

There is only a similaritiy of empowerment goals perception among BMT BIF with Ledok Timoho women's empowerment group. While, there are similarities and differences in perception of empowerment process; the similarities take place in perception of capital and religion program, and the difference perception is in training aspects. In addition, there is a similarity perception of empowerment outcomes in economic, religious, and social among BMT BIF with Ledok Timoho women's empowerment group. Furthermore, there are similarities and differences of perception in empowerment constraints. The similarities perception are marketing constraints, flurry of the participants, and awareness of the participants. Meanwhile, constrain that perceived different by them are limitation of BMT staff and limited access to soap raw materials. 


\section{References}

Adnan, M.A., Ajija, S.R. (2015). The Effectiveness of Baitul Maal Wat Tamwil in Reducing Poverty the Case of Indonesian Islamic Microfinance Institution. Humanomics 31 (2), pp.160-182.

Al Arif, M. N. R.. (2012). Lembaga Keuangan Syariah.Bandung: Pustaka Setia.

Alwan, S.M. (2011). Kontribusi BMT Terhadap Pemberdayaan Ekonomi Perempuan (Studi pada BMT Wilayah Tangerang Selatan). Jakarta : UIN Syarif Hidayatullah.

Aziz, M.A. (2004). Pedoman Pendirian BMT (Baitul Maal wa Tamwil., Jakarta: Pinbuk Press.

Baron, R.A. dan Paulus, P.B. (1991). Understanding Human Relations: A Practical Guide to People at Work, Edisi ke-2, Boston: Allyn \& Bacon.

Cangara, H. (2010). Pengantar Ilmu Komuniksi. Jakarta: Rajagrafindo Persada.

Devito, J.A. (1997). Komunikasi Antar Manusia. edisi ke-5.Penerjemah; Agus Maulana. Jakarta: Professional Books.

Diah, Y. (2013). Dampak Pemberdayaan Masyarakat Bagi Perempuan (Studi tentang Pelaksanaan CSR PT. Badak NGL terhadap Anggota Perempuan Kelompok Tani Lestari di Tanjung Laut Indah, Bontang Selatan, Bontang), Tesis: Universitas Gadjah Mada.

Goodacre, P. dan Follers, J. (1987). Communicating Accros Cultures. Wenworth, NSW: Sosial Science Press.

Gudykunts, W.B. dan Kim, Y.Y. (1992). Communicating with Strangers; An Approach to Intercultural Communication. Edisi Ke-2. McGrawHill.

Hadi, R., Wahyudin, U., Ardiwinata, J.S., Abdu, W.J. (2015). Education and Microfinance: an Alternative Approach to the Empowerment of the Poor People in Indonesia. SpringerPlus 4 (1), 244. 
Hardi, E.A.(2013). Analisis Pemberdayaan Masyarakat Muslim Miskin Melalui Qardul Hasan (Studi Kasus Program Baitul Maal BMT Beringharjo Yogyakarta). Tesis: Universitas Gadjah Mada.

Hardjana, A.M. (2003). Komunikasi Intrapersonal \& Interpersonal. Yogyakarta: Kanisius.

Jati, H.K.K. (2014). Pengaruh Pelaksanaan Program PNPM Mandiri Respek dalam Upaya Penanggulangan Kemiskinan di Kabupaten Mimika. Tesis: Universitas Gadjah Mada.

Mefalopulos. P. (2008). Development Communication Sourcebook. Broadening the Boundaries of Communication. Washington DC: World Bank.

Mubyarto. (2000). Membangun Sistem Ekonomi. Yogyakarta: BPFE.

Mulyana, D. (1996). Komunikasi Antar Budaya: Panduan Berkomunikasi dengan Orang-orang Berbeda Budaya. Bandung: Remaja Rosdakarya.

Mulyana, D. (2003). Ilmu Komunikasi: Suatu Pengantar. Bandung: Remaja Rosdakarya.

Mulyana, D. (2007). Ilmu Komunikasi: Suatu Pengantar, Bandung : Remaja Rosdakarya.

Nihayah, A.Z. (2014). Pengaruh Program Simpan Pinjam Kelompok Perempuan Terhadap Pendapatan Usaha Mikro Kecil dan Poverty Reduction dalam Perspektif Ekonomi Islam. Tesis: Universitas Gadjah Mada.

Ngadiman, Pambudi, D., Kusuma Wardani, D., Sabandi, M. (2014). Determinants of Accounting Information Technology Adoption in Syaria Micro Financial Institutions. Asian Social Science 10 (14), pp. 93-105.

Pearson, J. C. dan Nelson, P. E. (1979). Understanding and Sharing: An Introduction to Speech Communicatio. Dubuque., Lowa; Wm. C. Brown. 
Rahmawati, H. (2015). Pemberdayaan Masyarakat Melalui Kawasan Wisata. Skripsi: Universitas Gadjah Mada.

Rarasati, W.P. (2007). Pemberdayaan Fakir Miskin melalui Lembaga Keuangan Mikro (LKM)-Kelompok Usaha Bersama (KUBE): Studi di Lembaga Keuangan Mikro (LKM).BMT Sejahtera di Hogoadi Mlati Sleman.Tesis: Universitas Gadjah Mada

Raymond S.R. (1983). Speech Communication: Fundamentals and Practice. Edisi ke-6, Englewood Cliifs. New Jersey: Prentice Hall.

Rich, A.L. (1974). Interacial Communication. New York: Harper \& Row. Ridwan, A.H., (2013). Manajemen Baitul Maal Wa Tamwil. Bandung: Pustaka Setia.

Safi'i, M. (2010). Ampih Miskin: Model Kebijakan Penuntasan Kemiskinan dalam Perspektif Teori dan Praktek. Averros Press.

Samovar, L.A. dan Porter, R.E. (1991). Communication between Cultures, Belmont, California: Wadsworth.

Sereno, K.K. dan Bodaken, E.M. (1975). Trans-Per Understanding Human Communication, Boston : Houghton-Mifflin.

Setyawati, R. (2002). Pemberdayaan Ekonomi Kelompok Miskin melalui $B M T$ di DIY. Tesis : Universitas Gadjah Mada, Yogyakarta.

Setyowati, A. (2014). Analisis Efektifitas Pemberdayaan Ekonomi oleh Pimpinan Cabang Muhammadiyah (PCM) Krembangan Terhadap Mantan Pekerja Seks Komersial (PSK) Pasca Penutupan Lokalisasi Dupak Bangunsari dan Tambak Asri Surabaya Tahun 2014. Tesis : Universitas Gadjah Mada.

Shihab, M.Q. (2005). Tafsir al-Misbah, Jakarta: Lentera Hati Shihab, M.Q. (1996). Wawasan al-Qur'an, Bandung: Mizan.

Suhartini, dkk. (2005). Model-Model Pemberdayaan Masyarakat, Yogyakarta: LKiS Pelangi Aksara.

Sulistiyani, A.T. (2004). Kemitraan dan Model-Model Pemberdayaan. 
Yogyakarta: Gaya Media.

Sugiyono, (2008). Metode Penelitian Kuantitatif, Kualitatif dan R\&D. Bandung: Alfabeta

Suyanto, B. (2005). "Pemberdayaan Komunitas Marginal di Perkotaan" in Moh. Ali Aziz et all. Dakwah Pemberdayaan Msyarakat. Yogyakarta: LKiS Pelangi Aksara.

Wahyudi, H. (2014). Implementasi Kebijakan program Pengembangan Wilayah Terpadu Sebagai Solusi Pemberdayaan Perekonomian Masyarakat di Kota Yogyakarta. Tesis: Universitas Gadjah Mada.

Wardiwiyono, S. (2012). Internal Control System for Islamic Micro Financing: An Exploratory Study of Baitul Maal wat Tamwil in the City of Yogyakarta Indonesia. International Journal of Islamic and Middle Eastern Finance and Management 5 (4), pp. 340-352.

Widiastuti, R.R. dkk. (2015). Pemberdayaan Masyarakat Marginal. Yogyakarta:Pustaka Belajar.

Wulandari, P., Kasim, S. (2016). Issues and Challenges in Financing the Poor: Case of Baitul Maal Wa Tamwil in indonesia. International Journal of Bank Marketing 34 (2), pp. 216-324. 


\section{Shirkah Author Guidelines}

Shirkah currently offers two routes to submit manuscripts. We highly recommend to submit the articles which are made using OJS (Open Journal System). Feel free register as author soon through visiting http:// shirkah.or.id/index.php/home/user/register. The authors may directly send their manuscripts, along with their resume, to shirkahiainsurakarta@ gmail.com. Please prepare your manuscripts, using following guidelines:

1. Manuscript must be written in English. Submitted articles should not have been published or be under review for publication with another journal.

2. Manuscript's length is about $15-20$ pages, typed in one-half spaced on A4-paper size.

3. Manuscript must include an $150-200$ word abstract and keywords.

4. Manuscript must be arranged as follows: Title, Name of Author, E-mail address, Abstract, Keywords, Introduction (including method if any), Discussion, Conclusion, References.

5. Manuscript's titles not more than ten words.

6. Manuscript must be submitted in Microsoft Word or RTF.

7. Arabic words should be transliterated according to the style of International Journal of Middle Eastern Studies.

8. Manuscript references are preferably derived from the up-to-date references.

9. The author's resume should be submitted separately, consisting of at least full name, institutional address, phone number, areas of studies, and recent publications (if any).

10. Shirkab use APA Style 6th edition (2010) as reference format writing. We suggest the use of a reference manager software such as Mendeley, Zotero, and Endnote at templating the citation style. APA Style to be used is as follows: 


\section{Book with single author}

Swann, G. M. Peter. (2014). The Economics of Innovation an Introduction. Cheltenhum \& Northampton: Edward Elgar.

in-text citation: (Swann, 2014)

\section{Articles in reference books}

Alatas, S. F. (2006). Islam and the Science of Economics in Abu Rabi', I.M. The Blackwell Companion to Contemporary Islamic Thought. USA: Willey-Blackwell (pp. 587-606).

in text citation: (Alatas, 2006)

\section{E-Book}

Hackett, Rosalind (2007). "Religous Dimentions of War and Peace: Introduction.” Dalam Gerrie ter Haar dan Yoshio Tsuruoka (Ed.), Religion and Society: An Agenda for the 21st Century (h. 3-6). Retrieved from http:// brill.nl.

in text citation: (Hackett, 2006)

\section{Master's thesis, from a commercial database}

McNieI, D. S. (2006). Meaning through narrative: A personal narrative discussing growing up with an alcoholic mother (Master's thesis). Available from ProQuest Dissertations and Theses database. (UMI No. 1434728)

in text citation: (Mc Niel, 2006)

\section{Doctoral dissertation, from an institutional database}

Adams, R. J. (1973). Building a foundation for evaluation of instruction in higher education and continuing education (Doctoral dissertation). Retrieved from http://www.ohiolink.edu/etd/

in text citation: (Adams, 1973) 


\section{Doctoral dissertation, from the web}

Bruckman, A. (1997). MOOSE Crossing: Construction, community, and learning in a networked virtual world for kids (Doctoral dissertation, Massachusetts Institute of Technology). Retrieved from http:/www-static. cc.gatech.edu/--asb/thesis/ in text citation: (Bruckman, 1997)

\section{Journal article with No DOI}

Bourkhis, K., and Nabi, M. S. (2013). Islamic and conventional banks' soundness during the 2007-2008 financial crisis. Journal Metrics, 22(2), 68-77.

in-text citation: (Bourkhis \& Nabi, 2013).

\section{Journal article with DOI}

Ichwan, M. (2012). The Local Politics Of Orthodoxy: The Majelis Ulama Indonesia in the Post-New Order Banten. Journal Of Indonesian Islam, 6(1), 166-194. doi:http://dx.doi.org/10.15642/JIIS.2012.6.1.166-194

In text citation : (Ichwan, 2012)

\section{Abstract as citation}

Hasan, N. (2012). Islamist Party, Electoral Politics And Da'wah Mobilization Among Youth : The Prosperous Justice Party (PKS) in Indonesia. Journal of Indonesian Islam, 6(1), 17-47. Abstract from http:// jiis.uinsby.ac.id/index.php/jiis/article/view/97

in text citation : (Hasan, 2012)

\section{Mass media article}

Sahal, Akhmad (2014, March 2). Kiai Sahal dan Realisme Fikih.Tempo Magazine, p. 120.

in text citation : (Sahal, 2014) 


\section{Research report}

Fisher, B. S., Cullen, F. T., \& Turner, M. G. (2000). The Sexual Victimization of College Women. Research Report.

in text citation : (Fisher, Cullen, Turner, 2000)

\section{Monograph}

Routray, Bibhu Prasad (2013), National Security Decision-Making in India (RSIS Monograph No. 27). Singapura: Rajaratnam School of International Studies.

in text citation : (Routray, 2013)

\section{Proceeding article}

Sudibyakto, Hizbaron, D.R., \& Jati, R (Ed.) (2009), Proceeding International Seminar Disaster Theory, Research and Policy. International seminar held by Sekolah Pascasarjana, Universitas Gajahmada, Yogyakarta, 8-9 Desember 2009.

in text citation : (sudibyakto and Jati, 2009)

\section{Paper conference/seminar/symposium}

Janutama, Herman Sinung (2011). "Kraton dan Hubungan Antar Agama." Paper presented in Seminar Kraton dan Panatagama held by Center for the Study of Islam and Social Transformation (CISForm), Yogyakarta, 17 November.

in text citation :(Janutama, 2011)

\section{Online article in web}

Shiva, (2006, February). Bioethics: A Third World Issue. Native-web. Diperoleh dari http://www.nativeweb.org/ pages/legal/shiva.html

in text citation : (Shiva, 2006) 


\section{Online research report}

Kessy, S. S. A., \& Urio, F M. (2006). The contribution of microfinance institutions to poverty reduction in Tanzania (Research Report No. 06.3). Retrieved from Research on Poverty Alleviation website: http://www. repoa.or.tz /documents_storage/Publications/Reports/06.3_Kessy_and_ Urio.pcif

in text citation : (kessy and urion, 2006)

\section{Holy book}

Qur an, $2(25)$

In text citation : (Q. al-Baqarah 2:25).

\section{Encyclopaedia}

Graycar, Adam (1992). Social Welfare Policy. Dalam Mary Hawkesworth dan Maurice Kogan (Ed.), Encyclopedia of Government and Politics (Vol. 1). London: Routledge.

in text citation : (Graycar, 1992)

\section{Interview}

Sultan Hamengkubuwono X (interview, 2011, April 19)

in text citation: (Hamengkubuwono, 2011)

\section{Documentary film}

Steijlen, Fridus (2008). A Day in the Life of Indonesia [documentary film, 58 minutes]. Leiden: KITLV Press.

in text citation : (Steijlen, 2008) 
Vol. 2 No. 1, January - April 2017 